\title{
Detection of monoclonal immunoglobulins by immunoelectrophoresis: a possible source of error
}

\author{
AM SMITH, RA THOMPSON, AND MR HAENEY \\ From the Supra Regional Protein Reference Unit, Department of Immunology, East Birmingham Hospital, \\ Bordesley Green East, Birmingham, B9 5ST, UK
}

SUMMARY The technique of immunoelectrophoresis (IEP) is widely employed in the qualitative analysis of serum immunoglobulins. The most commonly used support media are agarose or agar gels, but the mobility of immunoglobulins is different in these two media. The presence of a small amount of a cathodal monoclonal immunoglobulin $\mathbf{G}$ may not be detected on IEP in agar if it is masked by larger amounts of polyclonal immunoglobulin of the same class. In these circumstances the use of agarose imparts to the monoclonal protein a different mobility from that of the bulk of the serum IgG and allows its positive identification.

Since its introduction ${ }^{1}$ immunoelectrophoresis (IEP) has proved a valuable tool in the qualitative investigation of proteins, particularly human serum immunoglobulins. Classically, the technique involves the separation of proteins by electrophoresis in a gel support medium, followed by visualisation of the separated proteins using specific antisera. Initial separation of the proteins depends on the charge carried by each protein. Polyclonal immunoglobulins, being of varying amino-acid composition, will exhibit a spectrum of mobility, moving as a broad band on electrophoresis and producing a pattern of smooth arcs with monospecific antisera to IgG, IgA, and IgM. A single clone of plasma cells synthesises immunoglobulin of one molecular type only. A number of such molecules possessing identical charge will travel as a discrete band on electrophoresis, producing characteristic distortion of the polyclonal arc on visualisation with specific antisera.

The diagnosis of a monoclonal immunoglobulin is suggested by serum protein electrophoresis on cellulose acetate, agarose, or some other support medium. Its verification requires visual interpretation of precipitation patterns on IEP. If only a small amount of monoclonal protein is present, there may be insufficient distortion of the polyclonal arc to allow identification of the monoclonal protein, particularly in the presence of a polyclonal increase of the same immunoglobulin class, and a faint gamma band seen on cellulose acetate electro-

Received for publication 3 September 1979 phoresis may then be interpreted as an artefact. This paper reports five cases in which the presence of a monoclonal protein could not be shown convincingly on IEP in agar, although all were clearly visible after IEP in agarose.

\section{Material and methods}

IEP in agar was carried out using $1.5 \%$ agar in $0.045 \mathrm{M}$ barbitone buffer $\mathrm{pH} \mathrm{8.6}$. The agar was poured on to a glass plate $(8 \times 8 \mathrm{~cm})$ to give a depth of agar of $1.7 \mathrm{~mm}$. The pattern of sample wells and antiserum troughs was cut as required. Electrophoresis of sera was carried out in an electrophoresis tank (Shandon Southern Limited) containing $0.045 \mathrm{M}$ barbitone buffer $\mathrm{pH} 8.6$ at a current of approximately $20 \mathrm{~mA}$ per plate for 45 minutes. The troughs were then filled with the relevant antisera and the plates incubated at room temperature overnight.

In this laboratory, a mixture of three monospecific antisera (anti-IgG, anti-IgA, and anti-IgM) is employed. These antisera were raised in sheep and absorbed where necessary to render them monospecific. Antisera to kappa or lambda light chains were obtained from Kallestadt Laboratories.

IEP in agarose was carried out using the CorningACI agarose film cassette system. This system includes pre-poured gel plates of $1 \%$ agarose in $0.065 \mathrm{M}$ barbital buffer, containing $0.035 \%$ disodium EDTA pH 8.6 and $50 \mathrm{~g} / \mathrm{l}$ sucrose. The pre-formed plates contain wells for the addition of test serum and troughs for the addition of antisera after electrophoresis. Electrophoresis is carried out in 
(a) Application

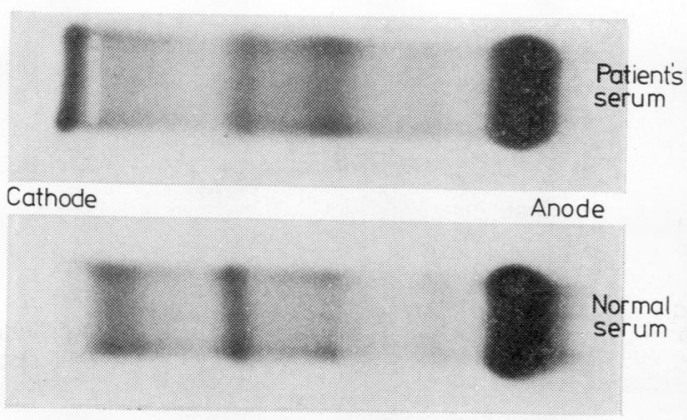

(c)

(b)

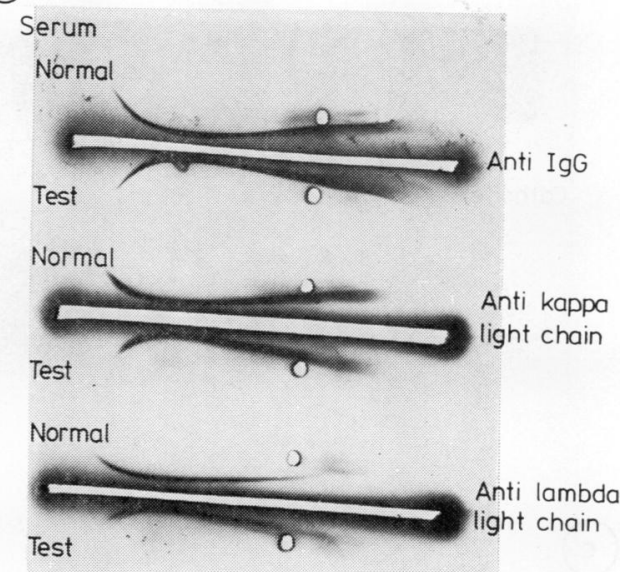

Serum

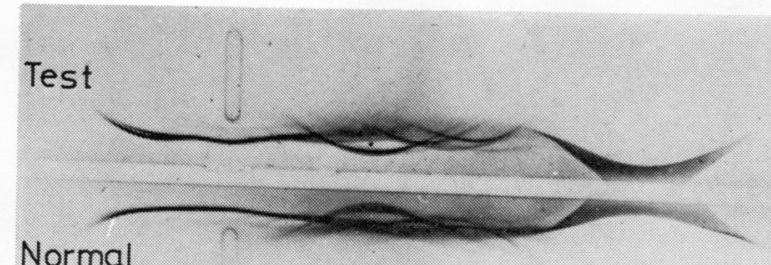

Normal
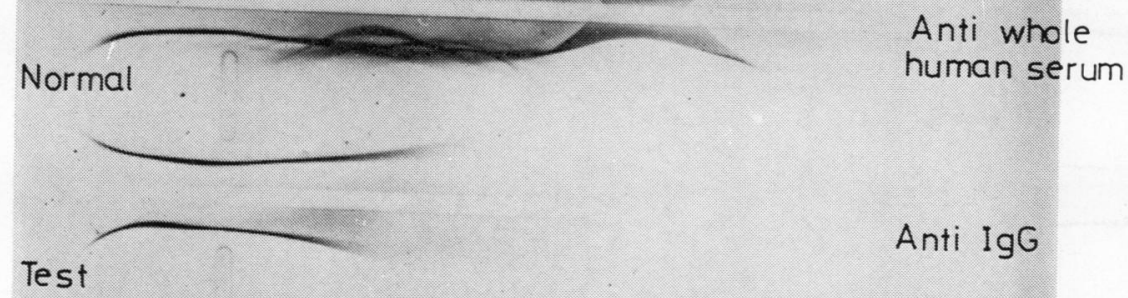

Anti IgG

Normal

Anti $\lg A$

Anti IgM

Test

Normal

Anti kappa

light chain

Fig. 1 Patient 1:

(a) Electrophoresis of serum in agarose.

(b) Immunoelectrophoresis of serum in agar.

(c) Immunoelectrophoresis of serum in agarose.

Anti lambda light chain

Anti IgG,

IgA, IgM 
(a) Application

$$
\text { well }
$$
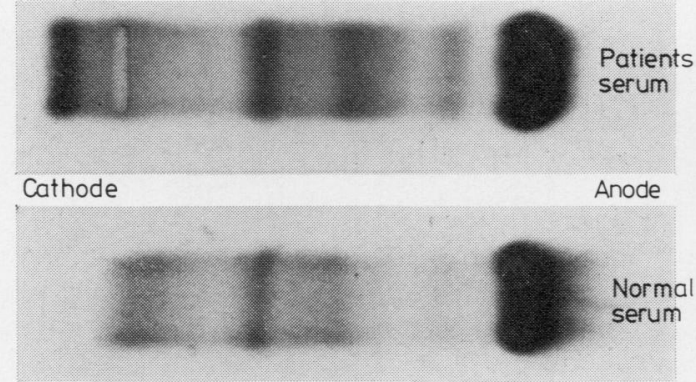

(c)

Serum

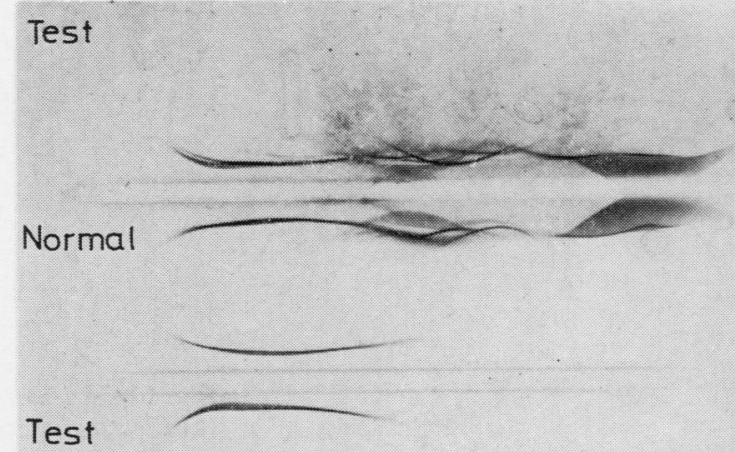

Normal

Normal

Test

\section{Test}
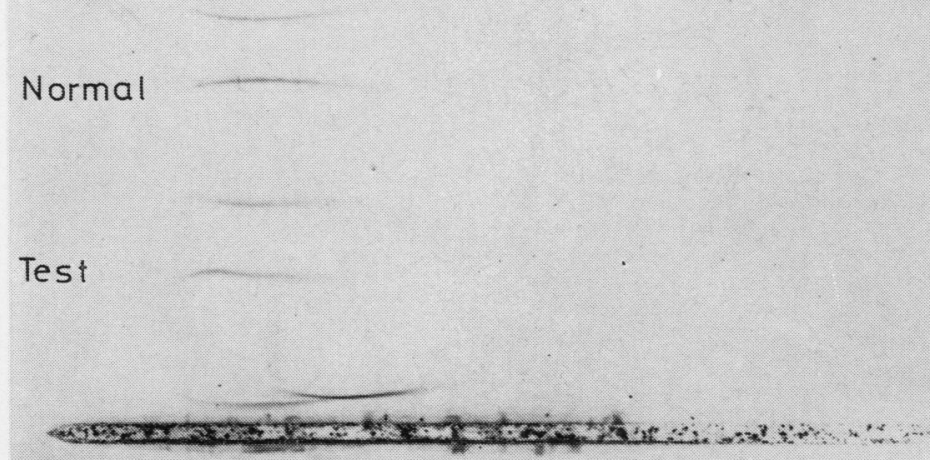

Anti IgG.

IgA, Ig $M$
Anti whole human serum Test

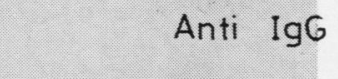

Anti kappa

\section{Anti Ig $M$} light chain

Anti lambda

Anti kappa light chain

Fig. 2 Patient 2:

(a) Electrophoresis of serum in agarose. (b) Immunoelectrophoresis of serum in agar. (c) Immunoelectrophoresis of serum in agarose.

Anti lambda Normal 
barbital buffer $0.05 \mathrm{M}$ containing $0.035 \%$ EDTA at $\mathrm{pH} 8 \cdot 6$. The cassette system comprises an electrophoresis tank and pre-set power supply, the time for an electrophoretic run being 30-40 minutes. After electrophoresis and the addition of antisera the plates are incubated overnight. The antisera usually employed are provided by Corning Medical as part of the above system and were found on testing to be monospecific for the stated antigen. The precipitation lines so formed may be enhanced by staining with Amido Black.

\section{Results}

Figures 1 and 2 show comparisons of electrophoresis and immunoelectrophoresis of two of the five sera in agar and agarose. In all cases the monoclonal protein in question is the IgG class. The results for IEP in agar show only the anti-IgG and anti-light chain plates. The Corning agarose system employs a battery of antisera, and the full results have been shown.

In each case diagnosis of the monoclonal IgG was difficult on the agar plates, but in the agarose system, the presence of a monoclonal IgG was quite obvious. Relevant laboratory details for each of the five cases are shown in the Table. IEP in agarose has also been of value in the confirmation of the presence of monoclonal IgM in sera.

Since the purpose of this study was to show a variation in results using different media, it was necessary to use the same antisera for both methods. The antisera usually employed in this laboratory were used in the Corning system in place of the Corning antisera. (A previous comparison of our in-house antisera and the Corning antisera had, in fact, shown identical results.) Preincubation of the test sera with agar or agarose did not affect the mobility of the monoclonal immunoglobulin.

\section{Discussion}

All five sera cited in this report contained a monoclonal IgG on IEP in agarose, which were difficult to visualise by IEP in agar. None of the patients had multiple myelomata as defined by accepted criteria: $:^{2}$ all were probable examples of 'monoclonal gammopathy'. It is well recognised that paraproteins may be detected in as many as $3 \%$ of patients aged over 70 years. $^{3}$

The increasing use of cellulose acetate electrophoresis to screen serum samples undergoing biochemical or immunological investigations has led to the frequent accidental detection of many asymptomatic monoclonal proteins.

Occasionally difficulty is found in the definitive identification of the nature of this monoclonal band. Positive identification of the immunoglobulin class involved is important in the long-term follow-up of such patients since serum paraproteins may be detected many years before clinical presentation with malignant immunocytoma. Also, in patients receiving chemotherapy for myeloma, assessment of the tumour size by serum paraprotein studies allows important monitoring during treatment. It is important, therefore, to establish that the apparent failure to detect a monoclonal protein on IEP is not an artefact due to the use of an inappropriate support medium. We have shown that, in some of these cases, the use of a different gel allows positive identification of the immunoglobulin class of the paraprotein.

\section{References}

${ }^{1}$ Grabar P, Williams CA. Méthode permettant l'étude conjugée des propriétés électrophorétiques et immunochimiques d'un mélange de protéines. Application au sérum sanguin. Biochem Biophys Acta 1953;10:193-4.

Table Laboratory details of five cases

\begin{tabular}{|c|c|c|c|c|c|c|c|c|}
\hline \multirow[t]{2}{*}{ Case } & \multirow{2}{*}{\multicolumn{2}{|c|}{ Age/Sex }} & \multirow{2}{*}{$\begin{array}{l}\text { Band on } \\
\text { cellulose acetate } \\
\text { electrophoresis }\end{array}$} & \multicolumn{2}{|c|}{ IEP findings in } & \multicolumn{3}{|c|}{ Immunoglobulin levels ( $\mathrm{g} /$ litre) } \\
\hline & & & & Agar & Agarose & $\operatorname{Ig} G$ & $\operatorname{Ig} A$ & $\operatorname{Ig} M$ \\
\hline 1 & 85 & $\mathbf{M}$ & $\gamma$ & Normal & $\begin{array}{l}\text { Monoclonal } \\
\text { IgG }(\lambda)\end{array}$ & $8 \cdot 45$ & 1.90 & $1 \cdot 40$ \\
\hline 2 & 98 & $\mathbf{F}$ & $\gamma$ & Normal & $\begin{array}{l}\text { Monocional } \\
\text { IgG }(\lambda)\end{array}$ & $12 \cdot 55$ & $3 \cdot 55$ & 0.65 \\
\hline 3 & 73 & $\mathbf{F}$ & $\gamma$ & Normal & $\begin{array}{l}\text { Monoclonal } \\
\text { IgG (א) }\end{array}$ & $14 \cdot 40$ & $2 \cdot 65$ & 0.50 \\
\hline 4 & 69 & $\mathbf{F}$ & $\gamma$ & Equivocal & $\begin{array}{l}\text { Monoclonal } \\
\operatorname{IgG}(\lambda)\end{array}$ & $19 \cdot 40$ & $5 \cdot 40$ & $1 \cdot 40$ \\
\hline 5 & 84 & $\mathbf{M}$ & $\gamma$ & Equivocal & $\begin{array}{l}\text { Monoclonal } \\
\text { IgG (א) }\end{array}$ & $7 \cdot 15$ & $2 \cdot 85$ & $1 \cdot 30$ \\
\hline
\end{tabular}


${ }^{2}$ Medical Research Council. Report on the first myelomatosis trial. Part I. Analysis of presenting features of prognostic importance. Brit J Haematol 1973;24: 123-39.

${ }^{3}$ Hällén J. Discrete gammaglobulin (M-) components in serum. Clinical study of 150 subjects without myelo- matosis. Acta Med Scand 1966;Suppl:462.

Requests for reprints to: Mr AM Smith, Supra Regional Protein Reference Unit, Department of Immunology, East Birmingham Hospital, Bordesley Green East, Birmingham B9 5ST, UK.

\section{Reports and Bulletins prepared by the Association of Clinical Biochemists}

The following reports and bulletins are published by the Association of Clinical Biochemists. They may be obtained from The Publishing Department, British Medical Journal (ACB Technical Bulletins), BMA House, Tavistock Square, London WC1H 9JR. Overseas readers should remit by British Postal or Money Order.

SCIENTIFIC REVIEWS (price $£ 1 \cdot 00 / \$ 2.00$ each)

1 The assessment of thyroid function March 1971 FV FLYNN and JR HOBBS

2 Renal function tests suitable for clinical practice January 1972 FL MITCHELL, N VEALL, and RWE WATTS

3 Biochemical tests for the assessment of fetoplacental function May 1975 CE WILDE and RE OAKEY

4 Test of exocrine pancreatic function March 1977 AH GOWENLOCK

5 Assay of cholinesterase in clinical chemistry March 1979 ELSIE SILK, J KING, and MARY WHITTAKER

TECHNICAL BULLETINS (price $£ 1 \cdot 00 / \$ 2.00$ each)

22 Bilirubin standards and the determination of bilirubin by manual and technicon AutoAnalyzer methods January 1971 BARBARA BILLING, RUTH HASLAM, and N WALD

23 Interchangeable cells for spectrophotometers and fluorimeters September 1971 ss BROWN and AH GOWENLOCK

24 Simple tests to detect poisons March 1972 BW MEADE et al.

25 Blood gas analysers May 1972 K DIXON

26 Kits for enzyme activity determination September 1972 SB ROSALKI and D TARLOW

27 Assessment of pumps suitable for incorporation into existing continuous flow analytical systems November 1972 A FLECK et al.

28 Routine clinical measurements of transferrin in human serum September 1973 K DIXON
29 Control materials for clinical biochemistry (5th edition) September 1973 JF STEVENS

30 Notes on the quality of performance of serum cholesterol assays September 1973 ss BROWN

31 Determination of uric acid in blood and in urine July 1974 RWE WATTS

32 A survey of amino acid analysers readily available in the United Kingdom September 1974 JE CARLYLE and P PURKISS

33 Definitions of some words and terms used in automated analysis November 1974 A FLECK, R ROBINSON, SS BROWN, and JR HOBBS

34 Measurement of albumin in the sera of patients January 1975 LINDA SLATER, PM CARTER, and JR HOBBS

35 Investigation of the validity of temperature correction factors for serum aspartate and alanine transaminases March 1975 SB ROSALKI et al.

36 Factors influencing the assay of creatinine November 1975 JGH COOK

37 A survey of enzyme reaction rate analysers readily available in the United Kingdom July 1977 RA SAUNDERS and RF BURNS

38 Transport of specimens for clinical chemistry analysis November 1977 P WILDING, JF ZILVA, and CE WILDE

39 A scheme for the evaluation of diagnostic kits May 1978 PH LLOYD

40 A practical guide to gamma-counting in radioimmunoassay January 1980 CE WILDE and D OTTEWELL 